\title{
Konsep Bioregion dalam Pengelolaan Sumberdaya Lansekap Arsitektur Nusantara
}

\author{
Dina Poerwoningsih ${ }^{1 *}$, Imam Santoso ${ }^{2}$ dan Erlina Laksmiani $W^{1}$ \\ ${ }^{1}$ Magister Arsitektur, Program Pascasarjana, Universitas Merdeka Malang, \\ ${ }^{2}$ Program Studi Arsitektur, Fakultas Teknik, Universitas Merdeka Malang, \\ *dina.poerwoningsih@unmer.ac.id
}

\begin{abstract}
ABSTRAK
Sumberdaya lansekap di Indonesia sangat kaya, beragam dan bernilai baik secara ekonomi sosial dan budaya. Keunikan dan keragamannya membutuhkan model pengelolaan yang tepat berbasis pada data dan keterlibatan stakeholder yang dilakukan secara terus menerus. Salah satunya adalah model pengelolaan lansekap alam dan budaya di komunitas atau kampung adat. Terdapat konsep hubungan yang sangat kuat antara manusia/masyarakat lokal dengan lingkungan alam dan budayanya. Oleh karenanya sudah seharusnya dilakukan upaya pengelolaan kampung adat termasuk lansekap ruangnya dalam cara pandang tersebut. Konsep dalam bidang pengelolaan sumberdaya lingkungan yang diangkat dalam tulisan ini adalah Konsep Bioregion. Tulisan ini dimaksudkan mengeksplorasi entitas-entitas lansekap arsitektur yang bersesuaian dengan Konsep Bioregion dalam pembahasan yang bersifat interdisipliner. Tulisan ini disusun dalam dua sub tema pembahasan yaitu (1) aspek-aspek permasalahan ruang dan lansekap arsitektur Nusantara dan (2) aspek-aspek dan permasalahan Bioregional yang terkait. Pembahasan lebih lanjut diharapkan menjadi peluang dalam studi arsitektur lansekap yang mendukung terwujudnya model pengelolaan lansekap kampung adat di Indonesia. Dalam bidang arsitektur, kampung adat lebih banyak dibahas sebagai entitas rumah atau bangunan, permukiman atau ruang luar mikro diantara bangunan. Tulisan ini berupaya mempertegas posisi lansekap kampung adat sebagai bagian dari ruang arsitektur. Beberapa metode perencanaan lansekap berkelanjutan yang telah dikembangkan secara eksplisit memasukkan perspektif ekologi lansekap di dalamnya. Tren lansekap berkelanjutan tersebut seharusnya menjadi motivasi untuk memposisikan lansekap kampung adat sebagai aset atau sumberdaya lingkungan. Pembahasan dalam tulisan ini menegaskan beberapa gagasan pengelolaan lansekap kampung adat dalam upaya konservasi arsitektur Nusantara yaitu (1) tesis adanya konsep boregion dalam substansi kearifan lokal lansekap arsitektur Nusantara dan (2) fleksibilitas skala ruang bioregional.
\end{abstract}

Kata kunci - manajemen lansekap kampung adat, konservasi lansekap kampung adat, konsep bioregion, arsitektur lansekap kampung adat

\begin{abstract}
Landscape resources in Indonesia are very rich, diverse and of good economic and social value. Its uniqueness and diversity requires an appropriate management model based on data and continuous stakeholder involvement. One of them is a model for management of natural landscapes and cultural in communities or traditional villages. There is a very strong concept of relationships between people / local communities and their natural and cultural environment. Therefore, efforts should be made to manage traditional villages including their spatial landscapes in that perspective. The concept in the environmental resource management raised in this paper is the Bioregion Concept. This paper is intended to explore architectural landscape entities that correspond to the Bioregion Concept in interdisciplinary discussions. This paper is organized into two sub-themes, namely (1) problem aspects of space and landscape of Nusantara architecture
\end{abstract}


and (2) related aspects and problems of Bioregional. Further discussion is expected to be an opportunity in the study of landscape architecture that supports the realization of a management model in traditional village landscape of Indonesia. In the field of architecture, traditional villages are more often discussed as houses or building entities, settlements or micro-outer spaces between buildings. This paper reinforces the position of the landscape as part of the architectural space. Some sustainable landscape planning methods that have been developed explicitly include a landscape ecology perspective. The sustainable landscape trend should be a motivation to position the traditional village landscape as an asset or environmental resource. The discussion in this paper confirms some ideas of traditional village landscape management in archipelago architecture conservation efforts, namely (1) the thesis of the concept of boregion in the local wisdom of the archipelago architectural landscape and (2) the flexibility of the scale of bioregional space.

Keywords - landscape management of traditional villages, conservation of traditional village landscapes, bioregion concepts, landscape architecture of Indonesian traditional village, landscape of Nusantara Architecture

\section{PENDAHULUAN}

Dalam bidang arsitektur, kampung adat lebih banyak dibahas sebagai entitas rumah atau bangunan, permukiman atau ruang luar mikro diantara bangunan. Tulisan ini dimaksudkan untuk membahas lansekap kampung adat sebagai bagian dari ruang arsitektur sekaligus sebagai sebuah sumberdaya lingkungan. Membaca arsitektur Nusantara sebagai sumberdaya lingkungan sangat erat dengan keingintahuan tentang proses habitasi dan bermukim sebuah komunitas yang melatarbelakangi eksistensi arsitektur Nusantara. Alihalih untuk membuka ranah teorisasi Arsitektur Nusantara, tulisan ini setidaknya memberi kontribusi dalam upaya konservasi lansekap arsitektur Nusantara.

Arsitektur Nusantara oleh sebagian besar akademisi diayakini sebagai peluang untuk menghadirkan dan mengembangkan teori arsitektur yang berakar dan berpijak pada bumi arsitektur dan praktek arsitektural itu sendiri. Teori-teori arsitektur modern hingga kini hanya membahas separuh bagian dari proses arsitektural, yakni proses gestasi atau terbentuknya bangunan (struktur gramatik, tipologi dan morfologi, styles, strategi desain) tetapi kurang memperhatikan separuh bagian yang lainnya, yakni proses habitasi dan bermukim yang melibatkan pengalaman komunitas yang tinggal atau hidup dalam suatu bangunan, tempat atau lingkungan. (Sudradjat, 2011)

Beberapa metode perencanaan lansekap yang telah dikembangkan secara eksplisit memasukkan perspektif ekologi lansekap di dalamnya. Tren ekologi lansekap sebagai pendekatan lansekap berkelanjutan tersebut seharusnya menjadi motivasi untuk memposisikan lansekap kampung adat sebagai aset atau sumberdaya lingkungan. Salah satunya adalah pendekatan Bioregion. Pendekatan bioregion bertujuan untuk menemukan keseimbangan antara kebutuhan masyarakat untuk mata pencaharian dan potensi sumber daya alam di wilayah mereka, yang ditetapkan berdasarkan kriteria ekologi, ekonomi, dan sosial (Miller, 1996). 


\section{Pengelolaan Lansekap Kampung Adat sebagai Sumberdaya Lingkungan}

Lansekap kampung adat bisa dianggap memiliki karakteristik yang sama dengan lansekap perdesaan yang didominasi lingkungan alamiahnya. Dalam beberapa aspek untuk mengenali karakter fisiknya dapat menggunakan parameter lansekap perdesaan juga. Lansekap perdesaan di desa-desa tradisional/vernakular/adat sebagian besar mencerminkan model pengelolaan sumberdaya alam dan lahan secara berkelanjutan oleh masyarakat desanya. Nilai-nilai keberlanjutan telah banyak digali dari desa-desa tradisional/vernakular/adat tersebut.

Penelusuran makna pembentukan ruang (placemaking) di lingkungan tradisional vernakular selalu menunjukkan adanya hubungan antara perilaku, kegiatan dengan ruang-ruang yang berbentuk. Korelasi antara ruang dan kegiatan sangat erat dan mencerminkan perilaku budaya dengan seting lingkungan dan bangunan. Performansi lansekap yang bernilai estetis arsitektural sebagaimana yang terlihat pada sawah teras Kampung Naga Jawa Barat, desa-desa tradisional di Bali hingga lansekap Satoyama di Jepang mencerminkan adanya tatacara dan adat kebiasaan yang telah berlangsung lama dalam mempertahankan sistem penggunaan lahan dan menyediakan sumber penghidupan masyarakat desa. (Rejeki, 2008) (Hidayat, 2010)

Lansekap kampung adat sebagai sumberdaya lingkungan memiliki makna yang lebih luas terhadap dukungan upaya konservasi arsitektur Nusantara yang tidak sekedar dipandang sebagai entitas rumah, bangunan ataupun perkampungan saja. Makna ini berkaitan dengan pendekatan perencanaan lansekap ekologi (Landscape-ecological Planning) merupakan cabang dari perencanaan lansekap yang berfokus pada perencanaan spasial, organisasi fungsi, dan hubunganhubungan dalam penggunaan lahan untuk mencapai tujuan-tujuan keberlanjutan (Brunckhorst, 2001). Pendekatan perencanaan tersebut memiliki karakter yang bukan sekedar terfokus pada pola dan proses ekologi, tetapi juga melibatkan nilai-nilai manusia, dan dimensi sosial ekonomi. Salah satu konsep ekologis dalam perencanaan ekologi adalah konsep bioregion.

\section{METODA PENELITIAN}

Tulisan ini dimaksudkan untuk menegaskan eksistensi arsitektur lansekap Arsitektur Nusantara sebagai bagian dari Arsitektur Nusantara. Bahwa arsitektur lansekap di Arsitektur Nusantara dapat menjadi bahasan khusus yang dalam bidang perencanaan lansekap ekologi (Landscape-ecological Planning) yang bersifat interdisipliner yang bertujuan sama dalam hal konservasi dan keberlanjutan masa depan (gambar 1).

Metoda yang dilakukan adalah metoda deskriptif eksplanatori pada beberapa aspek bahasan. Dalam upaya eksplanatori, tulisan ini mengambil contoh kasus untuk memperluas bahasan setiap aspek. Kasus yang diambil adalah Kampung Adat Marapu Sumba Barat, NT'T sebagai kampung adat yang representatif dalam bahasan kekayaan seting natural lansekap, sekaligus dalam bahasan kekayaan filosofi bentuk dan makna Arsitektur Nusantara. 


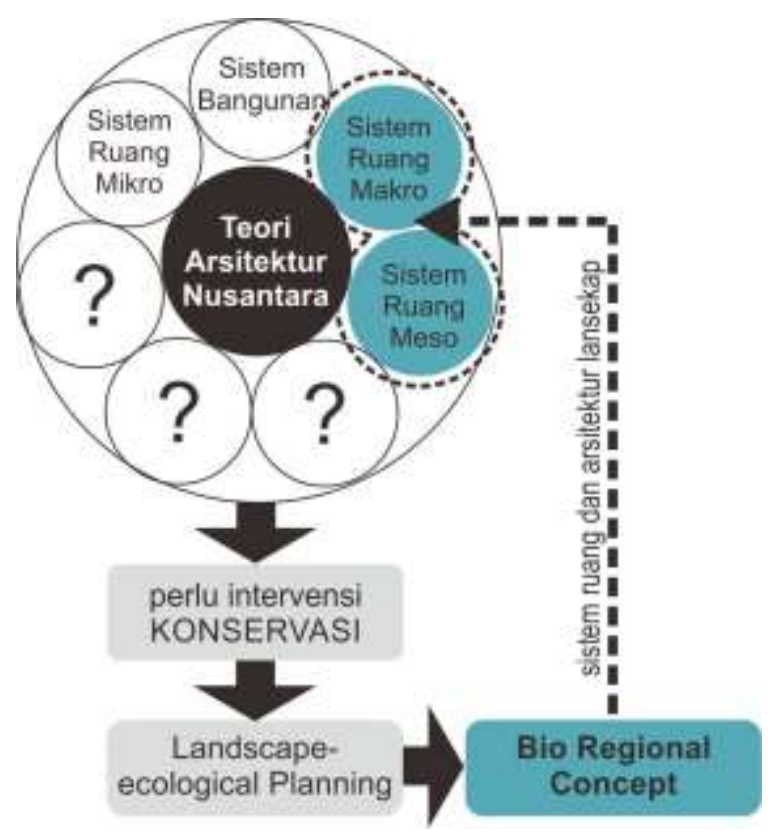

Gambar 1. Mapping mind lansekap Arsitektur Nusantara dan Landscape-ecological Planning)

\section{HASIL DAN PEMBAHASAN}

Tradisi Kampung Adat sebagai Representasi Konsep Hubungan Manusia dan Lingkungan

Karakteristik lansekap arsitektur Nusantara dipengaruhi oleh lokasinya yang terbentang di wilayah garis katulistiwa. Hubungan antara tradisi masyarakat dan alam sangat kuat berada pada seting yang mengindikasikan adanya keunikan pada lansekap arsitektur Nusantara. Salah satu lingkungan kampung adat yang mencerminkan kekhasan lansekap arsitektur Nusantara adalah Kampung Adat di Nusa Tenggara
Timur. Kampung tersebut disebut oleh sebagian besar peneliti merupakan warisan leluhur yang mampu bertahan ratusan tahun sebagaimana terlihat pada artefak bangunan dan ruang yang mencerminkan peradaban megalitikum. Penelitian terdahulu yang pernah dilakukan antara lain Winandari et al., (2006), Tanrim et al. (2014), telah cukup menjelaskan karakteristik peradaban megalitik kampung adat di wilayah Sumba. Artefak bangunan tradisional dan kondisi sosial budaya masyarakat saat ini masih menunjukkan jejak-jejak megalitik tersebut.

Penelitian Geria (2014) mencermati eksistensi permukiman dan bentuk-bentuk megalitik serta fungsinya dalam kehidupan masyarakat setempat. Hasil penelitian terhadap obyek arsitektur permukiman Rindi Praiyawang (salah satu kampung adat di Sumba) mengindikasikan adanya kearifan ekologis yang telah membentuk kehidupan masyarakat, baik yang bersifat sakral maupun profan.

Tradisi Pasola adalah salah satu representasi hubungan antara perilaku budaya dengan seting lingkungan dan bangunan. Sebagian besar masyarakat agraris di wilayah tropis katulistiwa melakukan tradisi penyambutan dan perayaan yang berkaitan dengan panen yang dikaitkan dengan keyakinan dan kepercayaan masyarakat setempat. demikian halnya yang terlihat salah satunya pada tradisi Pasola. Tradisi Pasola adalah tradisi permainan ketangkasan dengan saling melempar lembing yang terbuat dari kayu. Tradisi ini dilakukan Suku Sumba di Pulau Sumba, Sumba Barat, Nusa Tenggara Timur. 
Keunikannya ada pada kompetisi melontar tombak dari dua kelompok dari atas punggung kuda yang sedang berlari kencang. Penamaan Pasola berasal dari kata "Sola" dengan imbuhan "Pa". Sola adalah pengertian dari sejenis lembing kayu yang digunakan untuk saling melempar dari atas kuda oleh dua kelompok yang berlawanan. Sementara itu, imbuhan "Pa" menekankan bahwa ini adalah sebuah permainan.Tradisi ini merupakan bagian dari upacara tradisional agama Merapu (agama Lokal Suku Sumba) yang biasanya diadakan setiap tahun antara bulan Februari hingga Maret secara bergiliran oleh empat kampung (Kodi, Lamboya, Wonokaka dan Gaura). Tradisi ini merupakan sebagai bentuk penyambutan tahun baru dan panen dalam kepercayaan Merapu.

Tradisi Pasola tidak lepas dari tradisi Nyale. Dalam pelaksanaannya, Tradisi Pasola akan diawali dengan Upacara Adat Nyale yang merupakan ritual dalam kepercayaan Merapu sebagai bentuk rasa syukur atas anugerah yang diperoleh. Upacara Nyale ditandai kedatangan musim panen dan cacing laut (Nyale) yang melimpah atau keluar di pinggiran pantai. Penentuan dimulainya ritual Nyale pun sangat unik, karena terdapat beberapa syarat yang musti dipenuhi. Pasola diadakan atau tidak itu bergantung pada Nyale yang didapat. Upacara Nyale dilakukan di wilayah perairan laut sementara tradisi Pasola dilakukan di bentangan padang yang luas (gambar 2). Kedua seting tersebut berbeda dan keduanya memiliki nilai lokalitas yang sangat kuat secara geografis dan ekologis. Terdapat dua realitas yang bisa mengarah kepada tesis tentang adanya nilainilai ekologis lansekap yang dijaga kuat dengan balutan tradisi adalah kelimpahan Nyale (cacing laut) dan eksistensi kuda. Dalam terminologi ekologi, eksistensi cacing Nyale dan kuda Pasola dapat disebut sebagai salah satu sumberdaya ekologi di lingkungan Kampung Adat Marapu Sumba Barat.
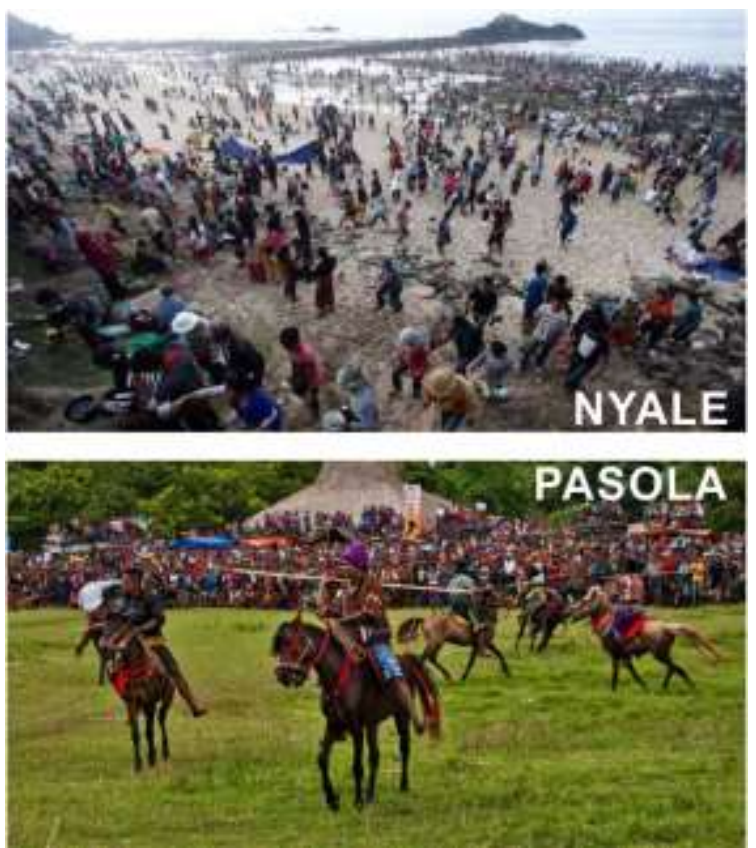

Gambar 2. Tradisi Pasola dan Nyale di Sumba

Barat, NTT. (Sumber: https://blogkulo.com/tradisiPasola-Nyale-suku-sumba/)

Menurut Geria unsur-unsur atau sumberdaya ekologi merupakan sumberdaya yang sangat penting dan menentukan kehidupan masyarakat setempat. Dengan demikian dapat diambil kesimpulan sebagai asumsi 
utama dalam tulisan ini adalah ada indikasi hubungan antara manusia dengan lingkungan biogeofisiknya. Lebih lanjut indikasi tersebut seharusnya diharapkan bisa menjelaskan adanya (1). pola hubungan yang bukan sekedar ketergantungan semata, (2). potensi dan kemampuan adaptasi manusia dengan lingkungannya, serta (3). potensi dan kemampuan manusia melangsungkan kehidupan tanpa merusak tatanan alam.

\section{Konsep Bioregional dalam Eksplorasi Sumberdaya Lansekap Arsitektur Nusantara}

Bioregion menunjukkan sebuah ruang geografis yang mengandung satu kesatuan ekosistem. Hal ini ditandai dengan bentuk muka bumi, tutupan vegetasi, budaya manusia, dan sejarah, seperti yang diidentifikasi oleh masyarakat lokal, pemerintah dan peneliti (Miller, 1996). Konsep bioregion bersesuaian dengan pandangan yang menyatakan bahwa tinggal dan menghuni suatu tempat berarti mengikuti kebutuhan dan kesenangan hidup yang disajikan secara unik oleh tempat tertentu, sekaligus berevolusi cara untuk memastikan hunian jangka panjang dari tempat tersebut.

Praktik-praktik masyarakat dalam menjalankan kehidupan suatu tempat adalah dengan menjaga keseimbangan dengan wilayah dukungannya melalui hubungan antara kehidupan manusia, makhluk hidup lainnya juga proses di siklus musim, cuaca dan air di planet ini sebagaimana diungkapkan oleh tempat hidup tersebut. Pandangan itu tentu saja berbalik dengan pandangan masyarakat yang mencari nafkah melalui eksploitasi tempat dan lingkungannya yang bersifat angka pendek. (Wahl, 2002)

\section{Bioregional sebagai Strategi Pelestarian Arsitektur Lansekap Nusantara}

Tulisan ini mengungkap pentingnya mengevaluasi kembali cara pandang arsitektur kita terhadap pengetahuan tradisional di seluruh dunia seraya mempertahankan kesadaran global keberlanjutan planet kita. Salah satunya adalah upaya identifikasi dan penelusuran yang simultan tentang arsitektur Nusantara. Melalui arsitektur Nusantara kita ditantang untuk lebih memusatkan perhatian kita tentang konteks lingkungan lokal kita secara langsung yang meliputi mitosnya, legenda, cerita rakyat dan belajar bagaimana berpartisipasi dengan tepat dalam ritual dan praktik yang mempertahankan keragaman dan ketahanan lokal.

Salah satunya kita harus menjadi pelaku yang sensitif dan masuk akal dalam perencanaan bioregional lokal kita. Miller (1996) menyatakan bahwa perencanaan bioregional merupakan proses organisasi yang memungkinkan orang untuk bekerja bersama-sama, memperoleh informasi, berpikir dengan hati-hati tentang masalah-masalah potensi dan wilayah mereka, tujuan dan sasaran, menentukan kegiatan, melaksanakan proyek, mengambil tindakan yang disepakati oleh masyarakat, mengevaluasi kemajuan, dan memperbaiki pendekatan mereka.

Menurut Wahl terdapat 3 (tiga) hal penting dalam konsep Bioregion. Pertama adalah menempatkan 
bioregion dalam konteks planet dan menekankan keunikan dan nilai intrinsik masing-masing bioregion. Kedua adalah batas bioregion terutama ditentukan oleh kualitas lokal dari proses pengaturan dirinya sendiri secara natural. Hal ini terkait dengan adanya budaya lokal tertentu dan jenis pemukiman. Ketiga adalah mengidentifikasi bioregion sebagai entitas geopolitik terhadap penghuni entitas akan bersifat sensitif terhadap berbagai kondisi lingkungan setempat.

Tujuan bioregional untuk menemukan keseimbangan antara kebutuhan warga masyarakat untuk mata pencaharian dan potensi sumber daya alam di wilayah mereka, yang ditetapkan berdasarkan oleh kriteria ekologi, ekonomi, dan sosial (Aberley 1994 dalam Miller, 1996). Tujuan ini bersesuaian dengan nilai-nilai dan semangat konservasi untuk keberlanjutan masa depan arsitektur Nusantara. Dalam ranah ekologi lansekap hal ini merujuk kepada daerah asal (homeland) sebagai ruang geografis yang meliputi sumber air mereka dan fitur kunci ekologi lainnya, produksi pangan, hutan, desa dan infrastrukturnya.

Menurut Miller (1996) terdapat 14 karakteristik pekerjaan manajemen bioregional yang dapat diidentifikasi sebagai berikut: (1.) Besar, wilayah yang layak secara biotik, (2.) Kepemimpinan dan manajemen, (3.) Sebuah struktur inti, koridor dan matriks, (4.) Keberlanjutan Ekonomi, (5.) Keterlibatan penuh dari stakeholder, (6.) Penerimaan Sosial, (7.) informasi yang komprehensif, (8.) Penelitian dan pemantauan, (9.) Penggunaan pengetahuan, (10.) Adaptif manajemen, (11.) Restorasi, (12.) Kerjasama pengembangan keterampilan, 13. Kelembagaan integrasi dan 14. Kerjasama internasional.

\section{Tesis Konsep Bioregion dalam Substansi Kearifan Lokal Arsitektur Lansekap Nusantara}

Masyarakat adat dan juga entitas kampung adat sesungguhnya sangat dekat dengan lingkungan alamnya. Budaya dan kebudayaan masyarakat adat menjadikan alam bagian yang ensensial. Bentuk-bentuk kebudayaan dihasilkan oleh manusia yang masih memiliki jiwa-jiwa tradisional yang luhur secara turun temurun yang merepresentasikan kebutuhan, keterkaitan dan ketergantungan terhadap sumberdaya alam di sekitarnya. Demikian pula sebaliknya eksistensi dari kekayaan alam sangat tergantung terhadap budaya lokal yang berkembang. Bertolak dari pemikiran resiprokal itulah seharusnya dalam upaya konservasi alam termasuk di dalamnya sumberdaya lansekap diperlukan juga pemahaman tentang kebudayaan manusia sebagai bagian utama komponen alam.

Indonesia sebenarnya memiliki model atau prototipe sistem konservasi dalam bentuk kearifan lokal (local wisdom). Beberapa obyek konservasi bahkan telah dilindungi oleh peraturan. Namun demikian peraturan dalam implementasinya di lapangan belumlah seperti harapan.

Kearifan lokal bisa dipahami sebagai seperangkat gagasan dan pandangan yang mengandung nilai-nilai sebagai landasan berperilaku yang diyakini dan mentradisi pada lingkungan lokal setempat. Tradisi ini mampu bertahan dan berkelanjutan dikarenakan 
bersifat produktif. Keberlanjutan sistem masyarakat tradisional ini tentu saja disebabkan oleh kesesuaian, keselarasan dan keharmonisan antara manusia dan alam lingkungan. Dalam beberapa contoh kampung adat sebut saja Kampung Naga dan Kampung Marapu secara biogeorafis sangat dekat dengan lingkungan alamnya (hutan, sawah, sungai, beserta seluruh sumberdaya lansekapnya) juga dekat dengan dinamika interaksinya dalam dimensi ruang dan waktu (gambar 2 dan gambar 3).

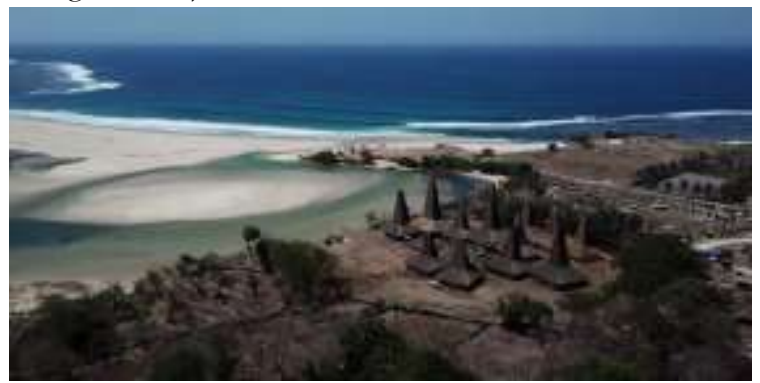

Gambar 2. Representasi Kedekatan biogeografis Kampung Marapu Ratenggaro

Kearifan lokal terbentuk dari interaksi yang panjang masyarakat dengan lingkungan hidupnya yang beragam membentuk suku-suku bangsa dengan keunikan budaya dan adat-istidatnya yang bernilai kearifan. Konsistensi masyarakatnya terus konsisten mepertahankan kearifan tradisi dan tidak tergerus arus globalisasi, maka dapat mampu membentengi serta meminimalisir kehancuran ekosistem dan kepunahan spesies. Masyarakat setempat yang menjalankan tradisi ini bisa disebut masyarakat adat (Wahyu, 2017).
Mendasarkan pada benang merah pemikiran di atas tulisan ini sekaligus menggagas sebuah tesis adanya atau telah dikembangkannya konsep bioregion dalam substansi kearifan lokal lansekap arsitektur Nusantara.

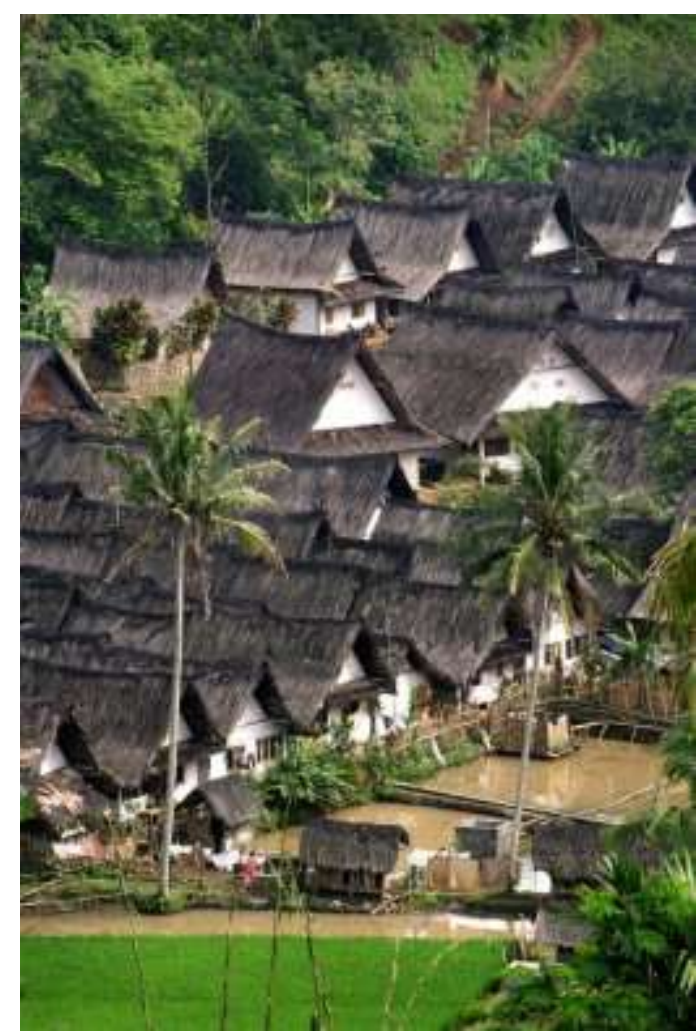

Gambar 3. Representasi Kedekatan biogeografis Kampung Naga. (sumber

bttps:/ /i.pinimg.com/originals/d0/2b/e2/d02be25b86f4156 bff378b7f20d10d5e.jpg) 


\section{Fleksibilitas Skala Ruang Bioregional}

Bioregionalisme berkembang dari ketertarikan akar rumput pada bagaimana membawa perubahan sosial yang akan membuat orang melindungi dan memulihkan lingkungan di tingkat lokal. Definisi apa pun dari konsep 'bioregion' harus selalu bersifat sementara untuk memungkinkan fleksibilitas dan kemampuan beradaptasi dengan karakteristik lokal yang unik dari wilayah mana pun. Fleksibilitas skala bioregional dalam tulisan ini diwarnai pemikiran Miller (1996) yang sesuai dengan situasi dan permasalahan ruang lansekap arsitektur Nusantara.

Dalam manajemen bioregional, tidak ada skala tunggal yang tepat untuk batasan area kegiatan. Ratusan ribu hektar bisa jadi cocok untuk manajemen beberapa ekosistem yang terdiri dari lereng gunung dan seluruh daerah aliran sungai. Ribuan hektar mungkin cukup untuk mengelola atau mengembalikan beberapa habitat atau untuk melindungi misal spesies tanaman tertentu. Pada setiap skala diperlukan alat dan kemampuan yang sesuai untuk membantu memenuhi tujuan manajemen.

Dalam hal penentuan stakeholder dan yurisdiksi institusional juga dapat berbeda-beda. Untuk alasan kepraktisan masyarakat, penghuni, pengelola sumber daya, dan lembaga pemerintah dapat bersama-sama mendefinisikan bioregion dalam pengertian yang oleh sebagian besar penduduk dan masyarakat yang bergantung pada apa yang dianggap sebagai sumber daya. Wilayah bioregion ini dibagi lagi menjadi area yang sesuai dengan daerah aliran sungai tertentu, tipe habitat, wilayah jelajah spesies tertentu, sumber pasokan kayu, zona pengembangan, dan sejenisnya. Menentukan seting skala proyek sangat penting untuk mencapai tujuan individu dan kelembagaan secara bersama-sama. Selanjutnya proses dialog, trial and error, dan adaptasi dari waktu ke waktu adalah cara terbaik untuk menentukan batas-batas bioregion. (Miller, 1996)

\section{KESIMPULAN}

Hasil pembahasan dalam tulisan ini dapat menyimpulkan bahwa pengelolaan bioregional dalam perencanaan lansekap berkelanjutan menjadi peluang dalam memahani entitas lansekap arsitektur Nusantara dan upaya konservasi arsitektur Nusantara.

Aspek-aspek permasalahan ruang dan lansekap arsitektur Nusantara memiliki substansi kearifan lokal yang memiliki kesamaan tujuan dengan konsep-konsep bioregional. Adanya kesamaan tersebut sangat penting dalam penentuan langkah-langkah strategis dalam perencanaan dan perancangan lansekap arsitektur kampung-kampung adat yang tersebar di seluruh Nusantara.

Aspek-aspek dan permasalahan perencanaan bioregional yang terkait erat dengan permasalahan ruang dan arsitektur (spatial architecture) adalah karakter fleksibilitas skala ruang bioregional. Fleksibilitas tersebut dapat menjadi kendala sekaligus menciptakan peluang untuk melakukan upaya terus-menerus untuk mencapai tujuan perencanaan lansekap berkelanjutan. Karakter fleksibilitas sebagai peluang dalam perumusan metoda-metoda yang inovatif dalam rangka pencarian 
batasan-batasan ekologis sekaligus nila-nilai lansekap arsitektur Nusantara yang sarat akan makna-makna kultural dan historis.

\section{REFERENSI}

Ahern, Jack. 2005. Integration of landscape ecology and landscape architecture: an evolutionary and reciprocal process. Issues and Perspectives in Landscape Ecology. Cambridge University Press.

Brunckhorst, David. 2001. Building Capital Through Bioregional Planning And Biosphere Reserves. University of New England. Australia.

Geria, I.M. 2015. Kearifan Ekologis Kampung Megalitik. Rindi Praiyawang, Sumba Timur. Forum Arkeologi Volume 27, Nomor 2, 2014 (99-108).

Hariyanto A.D., Asri A., Nurdiah E.A., Tulistyantoro L. 2012. Hubungan Ruang, Bentuk dan Makna pada Arsitektur Trasisional Sumba Barat. Laporan Penelitian LPPM Universitas Kristen Petra. Surabaya.

Hidayat, Imawan Wahyu. 2010. Landscape ecological pattern of tropical agroforestry efforts at educational forest landscape of Mount Walat, Sukabumi. Jurnal Ecotrophic.

Iskandar, J. 2001. Manusia Budaya dan Lingkungan. Humaniora Utama Press. Bandung.

Klett, J.E. and Cummins, A. 2013. Sustainable Landscaping. Colorado State University, community service provider extension. http://www.ext.colostate.edu/pubs/garden/072 43.html (accessed 15 July 2013).
Natori, Yoji. Fukui, Wataru. Hikasa. Mutsumi. 2005.

Empowering nature conservation in Japanese rural areas: a planning strategy integrating visual and biological landscape perspectives. Landscape and Urban Planning 70: 315-324.

Miller, K. R. 1996. Balancing The Scales: Guidlines for Increasing Biodiversity's Chances Through Bioregional Mangement. World Resources Institute. New York.

Rejeki, VG Sri. Nindyo Suwarno, Haryadi. 2007. Nilai vernacular dalam penataan lingkungan pada permukiman lereng gunung, Stusi di Desa Kapencar, Lereng Gunung Sindoro, Wonosobo. Dinensi Teknik Arsitektur (35) 190 - 198.

Saraswati T., Day M.A.R., 2017. Kampung Adat Deri Kambajaya di Kabupaten Sumba Tengah sebagai Living Museum. Proseding Seminar Nasional Arsitektur dan Tata Ruang (SAMARTA). Bali.

Sudradjat, I. 2011. Membangun Sistem Teori Arsitektur Nusantara : Merubah Angan-Angan Menjadi Kenyataan. bttps://laciarsip.wordpress.com /tulisan/kompilasi-tulisan/sudradjat-iwan/

Tanrim, C.F, Stefani Y.M., Cynthia K., Stefanie,W., Wijaya J.L. 2014. Sistem Struktur Rumah Adat Barat Rattenggaro. Prosiding Temu Ilmiah IPLBI 2014.

Wahl D.C. 2002. Bioregionalism-Living with a Sense of Place at the Appropriate Scale for Self-reliance An excerpt from 'Exploring Participation'. https:/ / medium.com/ age-of-awareness/

Winandari R. 2017. Adaptasi Teknologi di Rumah Adat Sumba. Jurnal Arsitektur Mintakat, Vol 18, No 2. halaman 109-114. 